\title{
PERLINDUNGAN PEREMPUAN \\ DAN ANAK KORBAN TRAFFICKING DI KABUPATEN KAPUAS HULU
}

\author{
Siti Hariti Sastriyani* \\ Pusat Studi Wanita Universitas Gadjah Mada
}

\begin{abstract}
This study aims to determine the cases of trafficking that occur in Kapuas Hulu. Some prevention efforts, a form of protection of victims and develop a model of protection of victims. Methods of data analysis performed using qualitative descriptive analysis with a sample of Sub Badau traffic being trafficked in Indonesia-Malaysia border. The results showed that some types of work done by the women and the children victims of trafficking are workers in places of entertainment, plantation workers, and etc. As for some of the factors that influence the occurrence of trafficking is the opening of the Postal Cross Border (PLB) Entikong Sanggau district. One of the prevention efforts that can be done by the Kapuas Hulu regency government is makes education and health as a priority program.
\end{abstract}

Kata Kunci: trafficking, faktor penyebab, upaya pencegahan

\section{PENDAHULUAN}

* Siti Hariti Sastriyani, Agustinus Supriyanto, Heri Susilowati \& Latifah 
Istilah trafficking merupakan istilah yang menarik banyak pihak. Sampai saat ini ada beberapa rumusan mengenai istilah Trafficking. Menurut Konvensi Internasional yang dikeluarkan pada bulan.Desember 2000 yang ditandai lebih 150 negara termasuk Indonesia, Trafficking adalah salah satu bentuk perbudakan modern yang disertai dengan proses perekrutan atau pengangkutan atau penindasan atau penampungan atau penerimaan dengan cara nacaman atau paksaan atau penculikan atau penipuan atau kebohongan atau penyalahgunaan kekuasaan untuk tujuan prostitusi atau kekerasan atau eksploitasi seksual atau kerja paksa dengan upah yang tidak layak atau praktek lain serupa perbudakan ${ }^{1}$.

Indonesia menggunakan istilah perdagangan orang. Hal ini tercantum dalam Undang-Undang Republik Indonesia nomor 21 tahun 2007 tentang Pemberantasan Tindak Pidana Perdagangan Orang pasal 1 yang berbunyi sebagai berikut: "Perdagangan orang adalah tindakan perekrutan, pengangkutan, penampungan, pengiriman, pemindahan, atau penerimaan seseorang dengan ancaman kekuasaan, penggunaan kekerasan, penculikan, penyekapan, pemalsuan, penipuan, penyalahgunaan kekuasaan atau posisi rentan, penjeratan utang atau memberi bayaran atau manfaat sehingga memperoleh persetujuan dari orang yang memegang kendali atas orang lain tersebut, baik yang dilakukan di dalam negara maupun antarnegara, untuk tujuan eksploitasi atau mengakibatkan orang tereksploitasi"2

Persatuan Bangsa-bangsa (PBB) mendefenisikan human trafficking atau perdagangan manusia sebagai rekruitmen, transportasi, pemindahan, penyembunyian atau penerimaan seseorang dengan ancaman atau penggunaan kekerasan, penculikan, pemalsuan, penipuan, penyalahgunaan kekuasaan/ posisi rentan atau memberi bayaran/ manfaat sehingga memperoleh persetujuan dari orang yang memegang kendali atas orang lain tersebut. Trafficking digunakan untuk kepentingan eksploitasi; bahkan prostitusi atau bentuk-bentuk eksploitasi seksual lainnya. Selain itu, trafficking dapat dikatakan sebagai kerja atau pelayananan paksa, perbudakan atau praktek-praktek lain yang sama dengan perbudakan, penghambaan atau pengambilan organ-organ tubuh. ${ }^{3}$

Di Indonesia, korban-korban trafficking seringkali digunakan untuk tujuan eksploitasi seksual misalnya dalam bentuk pelacuran dan pedophilia, bekerja pada tempat-tempat kasar yang memberikan gaji rendah seperti perkebunan, di jermal, pembantu rumah tangga, pekerja restoran, tenaga penghibur, perkawinan kontrak, buruh anak, pengemis jalanan, selain berperan sebagai pelacur. Korban trafficking biasanya anak dan perempuan yang berusia muda dan belum menikah, anak perempuan perceraian, serta mereka yang pernah bekerja di pusat kota atau luar negeri. Umumnya sebagian penghasilannya diberikan kepada keluarga. Anak korban trafficking seringkali 
berasal dari masyarakat yang diharapkan dapat menambah penghasilan keluarga.

Menurut data Badan Reserse dan Kriminal Markas Besar Kepolisian Republik Indonesia (Bareskrim Mabes Polri), TPPO (Tindak Pidana Perdagangan Orang) di Indonesia yang dilimpahkan ke Kejaksaan mulai tahun 1999 adalah 77,46\% dari 173 kasus; 66,67\% dari 24 kasus (2000); 72,07\% dari 179 kasus (2001); 58,06\% dari 155 kasus (2002); 53,60\% dari 125 kasus (2003); dan $53,48 \%$ dari 43 kasus pada tahun 2004. ${ }^{4}$ diungkapkan bahwa korban perdagangan manusia untuk pengantin pesanan atau disebut mail order bride banyak terjadi di Kalimatan Barat. Dari tahun 1987 sampai dengan 2001 telah terjadi lebih dari 20.000 perkawinan pria Taiwan dengan pengantin pesanannya dari Kalimantan Barat. Di antara mereka ada yang berbahagia, tetapi ada sejumlah istri yang melaporkan bahwa mereka dipekerjakan sebagai budak di rumah suami, rumah mertua, dengan jam kerja yang panjang, tanpa gaji, dan tidak diperlakukan sebagai anggota keluarga, bahkan ada yang dipaksa suaminya masuk industri seks atau di(Koalisi Perempuan Indonesia, Direktorat Pendidikan Masyarakat, 2008)jual di rumah bordil ${ }^{5}$.

Dari data lain, yang bersumber korban perdagangan orang sebanyak 3.127 orang, sebagian besar korbannya adalah perempuan dewasa (69 \%), sebanyak 25 \% korban adalah anak, dan sisanya 7 \% adalah laki-laki dewasa. Data korban perdagangan orang berdasarkan daerah asal yang bersumber dari IOM per Mei 2005- April 2008, terbanyak berasal dari Kalimantan Barat. Akhirakhir ini, korban perdagangan orang bertujuan untuk adopsi baik bayi maupun anak-anak semakin bertambah. Menurut Polda Kalimantan Barat sudah puluhan; bahkan ratusan bayi di bawah umur satu tahun dari Pontianak yang telah dijual di Malaysia Timur. Bayi tersebut dijual jutaan rupiah harganya; bahkan ada yang dijual dengan harga 30 juta rupiah.

Trafficking juga marak terjadi di Batam dengan kasus perdagangan bayi yang dijual ke Malaysia dan Singapura. Menurut Terre des Hommes (TDH) tercatat sekitar 210 bayi Indonesia diperdagangkan selama 5 tahun terakhir ini. Di Jakarta terungkap kelompok Rusdiana mengaku menjual 60 sampai 80 bayi, yang dijual di Amerika, Finlandia, dan Irlandia. Bayi-bayi yang diperjualbelikan umumnya diperoleh dari kehamilan para TKW yang mendapat penistaan seksual dari majikan, perselingkuhan, kekerasaan seksual, atau kehamilan yang tidak diinginkan. Kelompok rentan yang perlu diperhatikan untuk pencegahan trafficking adalah anak terlantar, anak jalanan, pengemis, pemulung, pengedar narkoba, dan sebagainya.

Kabupaten Kapuas Hulu, yang akan segera meresmikan pintu resmi atau Pos Lintas Batas (PLB) Nanga Badau akan membuka peluang baru dengan bisnis pengiriman tenaga kerja perempuan dan anak-anak untuk bekerja di 
Malaysia Timur. Akses dan kemudahan jalan darat merupakan peluang letak geografis ke Malaysia Timur, dan kemudahan untuk pergi dengan menggunakan jalan darat, menjadi incaran para PJTKI yang berada di luar Kalimantan Barat untuk menfaatkan pengiriman TKI/ TKW dengan transit melalui Kalimantan Barat.

Sebagai contoh kasus adalah kasus di Kecamatan Nanga Badau, Kecamatan perbatasan dengan Serawak ketika ekonomi Kecamatan Badau masih berkembang dengan maraknya illegal logging pada tahun 2006. Ketika itu, perempuan dan anak korban yang berhasil melarikan diri melalui jalur Badau maupun yang dipulangkan oleh kantor imigrasi Malaysia (Deportasi), kemudian setelah sampai di Badau, oleh oknum-oknum yang tidak bertanggung jawab para perempuan dan anak tersebut dipekerjakan sebagai pelayan di tempat-tempat karaoke. Setelah illegal logging dilarang pemerintah, juga masih terdapat beberapa tempat karaoke yang mempekerjakan perempuan-perempuan sebagai pelayan minuman maupun pelayan seksual secara terselubung dan dengan imbalan yang minim.

Penelitian terhadap perdagangan anak dan perempuan yang pernah dilakukan oleh PSKK UGM pada tahun $2002^{6}$ yang dituangkan dalam judul "Kekerasan Seksual dan Gagasan Kebijakan" menyatakan bahwa praktek perdagangan anak dan perempuan untuk tujuan seksual (PAPUTS) di Kota Semarang dilakukan di lesehan teh poci, lokalisasi Sunan Kuning, wisma, panti pijat, diskotik, salon, dan perumahan penduduk. Kekerasan yang dialami korban PAPUTS berupa kekerasan fisik, seksual, mental, dan penelantaran. Adapun bentuk kekerasan yang paling membuat trauma korban adalah kekerasan seksual, seperti pangris (jepang baris) yaitu melayani laki-laki dalam jumlah banyak dalam waktu satu kali booking (4-7 orang), tindhikan yaitu melayani seksual yang alat kelamin laki-laki penikmatnya memakai antinganting, sodomi, dan seks oral. Para perekrut korban PAPUTS di Semarang sebagian besar adalah para pelacur. Anak-anak yang menjadi sasaran atau yang dijerat dalam sindikat tersebut adalah tetangga sendiri, saudara, dan kenalan di dalam perjalanan. Melihat kasus ini, sangat mungkin bahwa mereka pada awalnya juga merupakan korban PAPUTS yang menjadi aktor PAPUTS di kemudian hari. Hal ini disebabkan mereka telah menikmati dunia yang serba permisif dan sangat mudah mencukupi kebutuhan hidup. Inilah suatu fenomena stockholm syndrom. Dari berbagai sindikat PAPUTS di Semarang, perdagangan anak perempuan di wisma merupakan jaringan yang paling rapi dengan dukungan sarana modern, baik di bidang transportasi, komunikasi, maupun strategi pemasaran. Selain itu, skala kerja samanya pun paling luas apabila dibandingkan dengan sindikat PAPUTS di lesehan teh poci dan lokalisasi Sunan Kuning. ${ }^{7}$ 
Penelitian lain tentang perdagangan perempuan juga pernah dilakukan oleh Devi Rahayu ${ }^{8}$ dengan judul“Tindakan Perdagangan Perempuan dalam Proses Pengiriman Buruh Migran di Madura. Dari hasil penelitian tersebut, diperoleh kesimpulan bahwa dalam proses pengiriman buruh migran di Bangkalan dan Sampang terdapat kasus yang timbul, terdapat unsur-unsur perdagangan perempuan yang berupa: (1) tindakan melintasi batas, yang merupakan keseluruhan proses pengiriman buruh migran dan dilakukan dengan melintasi perbatasan wilayah Indonesia, (2) adanya tindakan kekerasan atau ancaman kekerasan, tindakan yang terjadi selama di lokasi penampungan, (3) Adanya penipuan, berupa pemberian janji untuk diberangkatkan bekerja ke luar negeri (telah membayar sejumlah uang), tetapi tidak terlaksana, (4) lilitan hutang, buruh migran berangkat ke luar negeri dengan tanggungan hutang yang nantinya dibayar dengan uang upahnya, (5) kekerasan dengan penyalahgunaan kekuasaan, tindakan majikan untuk menyimpan dokumen dan sebagai pihak yang berkuasa, (6) kerja paksa atau kondisi seperti perbudakan, yang dialami buruh migran di tempat kerja..

Perdagangan bayi sebagai salah satu modus operandi trafficking dilakukan dalam beberapa bentuk, antara lain: penculikan bayi, penculikan ibu yang tengah hamil, mengikat orang tua si bayi dengan utang piutang sehingga harus menyerahkan anaknya secara terpaksa. Ada banyak alasan mengapa anak di bawah umur menjadi subyek perdagangan orang dari dan ke seluruh Indonesia, seperti dijadikan sebagai pembantu rumah tangga, jermal, pekerja seks komersial, pengemis, buruh perkebunan, buruh pabrik, pengedar narkoba, adopsi dan pernikahan. ${ }^{9}$

Dalam lokakarya "Bali Process mengenai Dukungan bagi Korban Perdagangan Manusia" di Hotel Intercontinental, Jimbaran, Bali, (7/11/2006), Menteri Pemberdayaan Perempuan menyinggung banyaknya perdagangan perempuan yang dijadikan sebagai buruh migran. Berdasarkan catatan Kedutaan Indonesia untuk Malaysia, pada 2005 terdapat 1.606 orang dipenjara karena tertangkap sebagai korban perdagangan. Banyak korban trafficking diseberangkan melalui transportasi laut. Hal ini mengingat kepulauan Indonesia masih sangat terbuka dengan pelabuhan-pelabuhan yang terbuka pula. Karena itu, tidak jarang perdagangan dapat lolos ke negara tetangga. Perlu ditingkatkan sensitifitas para aparat penjaga di lokasi atau gerbang lintas batas baik darat udara maupun laut untuk waspada dan mencurigai seseorang dengan membawa beberapa rombongan perempuan atau anak-anak. ${ }^{10}$

Perdagangan perempuan kini semakin marak, beberapa kasus di antaranya "di Kudus, 6 Penjual Perempuan Diringkus Sindikat Trafficking di Yogya Dibongkar". Dalam hal ini, Poltabes Yogyakarta menangkap pelaku perdagangan manusia. Adapun tersangka berasal dari Temanggung Jateng, 
sedangkan korban dua orang yang mawar dan Melati (bukan nama sebenarnya) hendak dibawa ke Belanda. Petugas juga mengamankan barang bukti, misalnya: satu unit mobil yang digunakan oleh pelaku untuk mencari beberapa wanita dari sejumlah daerah, kamera, foto-foto bugil sejumlah wanita dan dokumen perjalanan ke luar negeri. ${ }^{11}$

Kasus yang lain yaitu sindikat perdagangan perempuan juga berhasil diungkap oleh jajaran Polres Kudus. Enam tersangka berhasil diringkus, sedangkan lima korban yang salah satunya masih berusia 16 tahun, selama dua minggu dipaksa menjadi pekerja seks komersial di kalimantan. Semula mereka dijanjikan akan dipekerjakan di toko swalayan di Pangkalanbun Kalimantan dan dijanjikan gaji sebulan Rp 10 jutaRp 15 juta. ${ }^{12}$

Kasus yang serupa juga terjadi dalam hal ini, di Solo Jawa Tengah sedikitnya 100 anak menjadi korban perdagangan anak (trafficking) sepanjang tahun 2007. Jumlah itu mungkin bertambah lagi sebab data tersebut hanya didasarkan pada data kasus perdagangan anak yang ditangani oleh beberapa LSM yang peduli terhadap anak. Kenyataan di lapangan selama ini menunjukkan, banyak korban perdagangan anak yang enggan melapor, baik kepada pihak berwajib ataupun LSM untuk mendapat pendampingan, dengan berbagai sebab seperti pelaku merupakan keluarga dekat, tidak memiliki pemahaman hukum yang memadai, mendapat ancaman dari pelaku dan lain sebagainya.

Sebagian besar anak-anak ditujukan untuk seks komersial, selain dipekerjakan ke luar negeri secara ilegal. Dalam menjalankan aksinya, pelaku perdagangan anak umumnya berkedok sebagai penyalur tenaga kerja ke luar negeri. Anak-anak yang berasal dari Solo dikirim ke berbagai daerah atau negara baik untuk dipekerjakan sebagai pekerja Seks komersial (PSK) ataupun tega migran ke luar negeri, melalui Batam dan Surabaya ${ }^{13}$

Pemerintah sudah berupaya untuk melindungi korban-koran trafficking melalui Undang-Undang Nomor 2 Tahun 2007 tentang Pemberantasan Tindak Pidana Perdagangan. Pada pasal 56 disebutkan, pemberantasan tindak pidana perdagangan orang, Pemerintah dan Pemerintah Daerah wajib mengambil langkah-langkah pencegahan dan penangan tindak pidana perdagangan orang. Dengan demikian perlindungan terhadap perempuan dan anak dari tindak perdagangan orang, meliputi (1) upaya pencegahan agar tidak terjadi tindak perdagangan pada perempuan dan anak. (2) upaya penanganan terhadap tindak perdagangan orang. Dalam Undang-Undang tersebut, juga disebutkan langkah-langkah upaya pencegahan tindak perdagangan orang sebagai berikut : pembentukan gugus tugas, advokasi, sosialisasi, pelatihan dan kerja sama,adanya peran serta masyarakat. Penanganan terhadap tindak pidana 
perdagangan orang meliputi penegakan hukum (penetapan sanksi pidana bagi pelaku dan orang yang terlibat), pelaksanaan perlindungan korban meliputi rehabilitasi, pemulangan dan reintegrasi sosial.

Landasan hukum tentang perlindungan terhadap perempuan dan anak berikut ini: KUHP, UU No. 8 Tahun 1981 KUHAP, UU No. 16 Tahun 1974 tentang Ketentuan Pokok Kesejahteraan Sosial, UU No. 1 Tahun 1990 tentang Keimigrasian, UU No. 13 Tahun 2003 tentang Ketenagakerjaan, UU No. 23 Tahun 2002 tentang Perlindungan Anak, UU No. 7 Tahun 1984 tentang Penghapusan Segala Bentuk Diskriminasi Terhadap Perempuan, UU No. 9 Tahun 1990 tentang Kepariwisataan, UU No. 3 Tahun 1997 tentang Peradilan Anak, Keppres No. 88 Tahun 2002 tentang Penanggulangan Perdagangan Perempuan \& Anak. ${ }^{14}$ (Ak, Syahmin Hukum Internasional Publik, 1999)

Sementara itu, dengan melihat semakin maraknya masalah perdagangan orang di berbagai negara, terutama di negara berkembang termasuk Indonesia, telah menjadi perhatian masyarakat internasional dan organisasi internasional terutama perserikatan Bangsa-Bangsa (PBB) serta belum jelasnya kapan rancangan Undang-undang tentang pemberantasan Pindak Pidana Perdagangan Orang disahkan oleh DPR menjadi Undang-undang, Dengan segala keikhlasan dan rasa kepedulian terhadap masalah perdagangan orang. Adolf Jouke Sondakh (Gubernur propinsi Sulawesi Utara) pada tanggal 6 Januari 2004 mengeluarkan Perda No.1 Tahun 2004 tentang Pencegahan dan Pemberantasan Perdagangan Manusia (trafficking) Terutama Perempuan dan Anak.

Maksud dikeluarkannya Perda ini adalah untuk melawan perdagangan manusia (trafficking) yang merupakan bentuk eksploitasi dan perbudakan manusia di zaman modern yang menimbulkan penderitaan kesengsaraan pada perempuan dan anak. Sementara tujuannya adalah untuk mencegah dan memberantas bentuk-bentuk trafficking baik untuk pekerjaan tertentu maupun untuk kegiatan seks komersial, menyelamatkan dan merehabilitasi korban trafficking, serta memberikan keadilan dan hukuman yang efektif terhadap pelaku maupun pihak-pihak yang mendukung trafficking ${ }^{15}$.

Berdasarkan latar belakang dan pemikiran tersebut di atas, serta dalam rangka meminimalkan jumlah korban diperlukan adanya model perlindungan perempuan dan anak korban trafficking serta upaya pencegahannya. Namun demikian sebelum disusun sebuah model perlindungan, perlu dilakukan kajian tentang kasus-kasus trafficking di kota Nanga Badau dn upaya-upaya yang dapat dilakukan dalam memenimalkan jumlah korban trafficking. Di masa yang akan datang kota ini tampaknya juga akan semakin cepat dengan dukungan berbagai kebijakan pemerintah seperti penetapan Kota Nanga Badau sebagai Pusat Regional bagian Utara Kabupaten Kapuas Hulu seperti yang 
dituangkan dalam RTRWK Kapuas Hulu, peningkatan jalan lintas utara serta yang terpenting adalah rencana pembukaan Pintu Gerbang Kedua bagi Kalimantan Barat setelah Entikong (Sanggau). Rencana jalan provinsi dari Lintas Selatan hingga Nanga Badau juga merupakan potensi besar mendorong pertumbuhan kota Nanga Badau.

Penelitian ini termasuk dalam kelompok penelitian kualitatif dengan populasi penelitian adalah Kabupaten Kapuas Hulu. Adapun sampel yang sengaja diambil adalah Kecamatan Badau karena di Kecamatan Badau telah berdiri Pos Lintas Batas di Nanga Badau. Kota ini menjadi lalu lintas trafficking karena letaknya di wilayah perbatasan dengan Malaysia. Pengumpulan data kuantitatif berasal dari data sekunder mengenai lokasi penelitian, korban trafficking, dan data pendukung lainnya. Adapun pengumpulan data kualitatif dilakukan dengan menggunakan PRA, FGD dan FDI pada para responden yang terbagi menjadi tiga kelompok. Kelompok pertama berfokus pada kasuskasus; kelompok kedua bentuk perlindungan, dan kelompok ketiga berfokus pada upaya pencegahan serta penyusunan model. Kegiatan ini dirancang untuk mengetahui potensi, dinamika dan kerangka perencanaan partisipatif untuk melihat faktor-faktor yang melatarbelakangi permasalahan trafficking di wilayah tersebut dan juga akan diketahui alternatif solusi permasalahan yang diinginkan oleh peserta. Metode analisa data yang digunakan dalam penelitian ini adalah metode deskriptif kualitatif. Berbagai data yang terkumpul akan diidentifikasi dan diklasifikasikan sedemikian rupa sesuai dengan kategori masing-masing, kemudian diadakan penganalisaan data, dengan tahapan sebagai berikut: (a) Menelah seluruh data yang diperoleh, baik data skunder maupun data primer yang diperoleh melalui PRA, FDI maupun FGD. (b) Pemilihan data dan informasi dalam satuan-satuan data dan informasi. (c) Kategorisasi data, baik menurut jenis, sifat maupun tingkat keterkaitan antara data satu dengan data lainnya.(d) Penafsiran data, dilakukan dalam kerangka analisis data dan informasi dengan cara menghubung-hubungkan data dan informasi, mencari sebab akibat, membuat(Media Perempuan, edisi no.3, 2005 hal.42) argumentasi, membuat diskripsi dan lain-lain. (e) Penarikan kesimpulan dan rekomendasi untuk menjawab berbagai permasalahan yang dituangkan dalam sebuah laporan akhir.

\section{PEMBAHASAN}

\section{Jenis Pekerjaan Korban Trafficking}

Berbagai jenis pekerjaan yang dilakukan perempuan dan anak korban trafficking di Kabupaten Kapuas Hulu, pertama, pekerja di tempat hiburan. Pos lintas batas di Entikong yang resmi dibuka tahun 1991 oleh Presiden Soeharto dapat ditempuh dari Pontianak dengan perjalanan selama lebih kurang 8 jam 
atau 10 jam dengan menggunakan bus atau kendaraan roda empat. Selain jalur resmi Entikong pada awal Agustus 1999 telah dibuka lagi jalur PLB , di Kecamatan Badau Kabupaten Kapuas Hulu dan di Kabupaten Sintang. Dengan dibukanya pos lintas batas resmi selain dampaknya menguntungkan untuk perekonomian kedua negara, tetapi juga melahirkan permasalahan yang tidak henti-hentinya, antara lain perpindahan batas/ patok antarnegara, pencurian kayu yang melibatkan warga kedua negara dan permasalahan tenaga kerja yang melibatkan anak dan perempuan untuk dikirim, dengan berkedok sebagai TKW yang akhirnya banyak dieskploitasi pihak-pihak yang mengambil keuntungan dari mereka. Peluang Menjadi Tenaga Kerja sejak dibukanya pintu resmi Entikong-Tebedu, membuka peluang baru dengan bisnis pengiriman tenaga kerja perempuan dan anak-anak untuk bekerja di Malaysia Timur. Akses dan kemudahan jalan darat merupakan peluang letak geografis ke Malaysia Timur, dan kemudahan untuk pergi dengan menggunakan jalan darat, menjadi incaran para PJTKI yang berada di luar Kal-Bar untuk menfaatkan pengiriman TKI/ TKW dengan transit melalui Kal-Bar.

Setelah di tempat majikan, banyak diantara mereka yang mendapat perlakuan yang tidak manusiawi dan pekerjaan tidak sesuai dengan perjanjian awal. Banyak diantara mereka ketakutan untuk melakukan perlawanan karena pasport mereka berada di tangan agen atau majikan sehingga untuk melarikan diri sudah merupakan keputusan yang sangat berani yang mereka ambil. Dengan tidak sesuainya perjanjian yang telah dijanjikan atau mengalami perlakuan yang tidak manusiawi, banyak perempuan dan anak-anak berupaya melarikan diri dengan cara-cara yang biasa mereka lakukan adalah melompat pagar rumah majikan, meminta tolong tetangga atau juga pergi dengan diamdiam pada malam hari, lari ke dalam hutan berhari-hari. Setelah berhasil melarikan diri karena mereka tidak berdaya di samping tidak mengerti situasi wilayah negara, dan juga pada saat melarikan diri mereka tanpa identitas sama sekali (bahkan banyak di antaranya hanya memakai baju yang di badan saja). Karena pasport selalu ditahan calo maupun majikan, yang bisa melarikan diri juga penuh pertaruhan. Jika bertemu dan dibantu oleh orang yang peduli akan nasib mereka, mereka akan diantarkan ke Konsulat RI atau Kantor Polisi, dan jika tidak beruntung mereka akan menemukan orang-orang yang menambah kesusahan/ penderitaan bagi mereka.

Sebagai contoh kasus adalah di Kecamatan Badau, Kecamatan perbatasan dengan Serawak ketika ekonomi Kecamatan Badau masih berkembang dengan maraknya illegal logging pada tahun 2006. Ketika itu, perempuan dan anak korban yang berhasil melarikan diri melalui jalur Badau maupun yang dipulangkan oleh kantor imigrasi Malaysia (Deportasi), kemudian setelah sampai di Badau, oleh oknum-oknum yang tidak 
bertanggung jawab para perempuan dan anak tersebut dipekerjakan sebagai pelayan di tempat-tempat karaoke. Setelah illegal logging dilarang pemerintah, juga masih terdapat beberapa tempat karaoke yang mempekerjakan perempuan-perempuan sebagai pelayan minuman maupun pelayan seksual secara terselubung dan dengan imbalan yang minim.

Kedua, Buruh perkebunan atau pabrik. Salah satu jenis pekerjaan yang dilakukan oleh para korban trafficking, antara lain bekerja di perkebunan karet di Malaysia. Berikut ini adalah kisah yang disampaikan oleh seorang ibu yang ingin memperoleh pendapatan yang layak, beliau rela mengajak putrinya yang masih di bawah umur untuk ikut bekerja di Malaysia, dan dalam kisahnya mengalami penangkapan oleh kepolisian Malaysia dan ibu tersebut beserta anaknya ikut di sel (penjara) malaysia, sehingga menimbulkan trauma pada anak tersebut.

Ketiga, pekerja migran. Pada dasarnya banyak tindakan perdagangan orang yang terjadi di masyarakat Kabupaten Kapuas Hulu. Akan tetapi kasuskasus tersebut tidak ter-expose. Dari beberapa informandiperoleh informasi bahwa kasus yang banyak terjadi adalah proses perekrutan dengan janji atau iming-iming pekerjaan yang layak dan gaji yang cukup besar. Setelah terjadi perekrutan dan pengurusan berbagai administrasi keperluan, kemudian para calon pekerja dikirim ke malaysia untuk dipekerjakan. Akan tetapi, setelah di Malaysia, jenis pekerjaan dan upahnya tidak sesuai dengan yang dijanjikan sehingga banyak dari mereka yang mengalami kekerasan, penipuan maupun ancaman melarikan diri.

Data International for Migration (IOM) sepanjang tahun 2007 menyebutkan pembayaran gaji mendominasi kasus TKI bermasalah di luar negeri yang berujung pada pendeportasian. Pekerja rumah tangga merupakan jumlah terbanyak TKI yang bermasalah. Berdasarkan data IOM pada periode Maret 2005- Oktober 2006, terdapat 1.650 TKI korban trafficking yang di pulangkan ke Indonesia melalui lembaga tersebut. Sebanyak 49 persen di antaranya bekerja sebagai pekerja rumah tangga, dan 90 persen merupakan kasus gaji yang tidak dibayar atau tidak sesuai dengan perjanjian awal.

Keempat, buruh perkebunan kelapa sawit. Kurang lebih $10 \%$ penduduk desa Lanjak bekerja di Serawak. Anak-anak Desa Lanjak yang bekerja di Malaysia sebagian dapat memperbaiki kehidupan keluarganya dan sebagian lainnya tidak. Perbaikan ekonomi dapat dilihat misalnya dari perbaikan kondisi keluarganya. Adanya anak-anak yang bekerja di Serawak tetapi tidak mampu memperbaiki keadaan ekonomi keluarganya disebabkan oleh selama tinggal di Serawak mereka hidup secara glamor. Dijumpai sebuah fenomena di Desa Lanjak yaitu banyak anak yang pergi ke Serawak untuk mencari nafkah; bahkan mereka pergi dengan mengorbankan kesempatan menempuh 
pendidikan di sekolah. Mereka mempunyai slogan lebih baik mendapat uang di Serawak daripada memperoleh ilmu di sekolah. Anak-anak di Desa Lanjak banyak yang putus sekolah dengan tujuan bekerja di Serawak. Hal itu terus terjadi walaupun sudah banyak pengarahan dari pihak sekolah dan desa. Para guru selalu mengajarkan bahwa pendidikan merupakan modal masa depan. Para aparat desa melalui berbagai kesempatan juga telah memberi penjelasan akan pentingnya pendidikan.

Salah satu kendala bagi aparat desa Lanjak adalah bahwa mereka yang pergi bekerja ke Serawak tidak memberi laporan ke desa. Dijumpai ada beberapa sekolah yang beberapa muridnya tidak melanjutkan sekolah untuk bekerja di Serawak, misalnya SD Kapar, SD Kelandan, dan SD Kelawi. Mereka banyak bekerja di Perkebunan Kelapa Sawit. Pekerjaan mereka misalnya membuat lubang untuk ditanami pohon kelapa sawit. Mereka pergi tanpa ada yang mengorganisasikannya. Hal itu terjadi karena di Serawak mereka mempunyai saudara atau keluarga yang sama-sama suku Iban. Alasan mereka bekerja di Serawak adalah untuk mencari nafkah. Dilihat dari asal usul mereka, di antaranya ada yang berasal dari keluarga miskin, tetapi tidak jarak sebenarnya secara ekonomi mereka berasal dari keluarga yang cukup. Mereka pergi ke Serawak kebanyakan dengan berjalan kaki selama kurang lebih lima hari lima malam.

Kelima, buruh perkebunan kayu lapis.Para pekerja migran yang termasuk korban trafficking, sangat rawan akan menjadi korban (1) Pekerjaanpekerjaan yang bersifat eksploitatif. Adanya beberapa perempuan lokal maupun anak usia sekolah yang dieksploitasi untuk bekerja di beberapa perkebunan yang terdapat di Kecamatan Badau. Para pekerja, baik laki-laki, perempuan; bahkan terdapat beberapa anak-anak usia sekolah berangkat menuju perkebunan sawit pukul 05.00 pagi dengan diangkut truk dan mereka harus bekerja sejak pagi hingga sore hari dengan upah yang relative minim, yaitu sebesar Rp 70.000 per hari. Setiap pagi, mereka menunggu di perempatanperempatan jalan desa. Hal ini dilakukan karena sebelum pukul 07.00 mereka harus sudah sampai perkebunan. Jika mereka terlambat, tidak akan menerima upah sama sekali dan jika mereka ingin pulang, hal ini tidak memungkinkan mengingat jaraknya yang cukup jauh. Masalah anak lainnya adalah banyaknya anak usia sekolah yang bekerja. Kesulitan ekonomi sering memaksa anak untuk bekerja. Sebagai anak-anak mereka memiliki hak untuk belajar, bermain serta mengalami tumbuh kembang secara wajar sehingga dapat diharapkan menjadi generasi penerus yang berkualitas. Karena kondisi ekonomi keluarga yang tidak memadai telah menyebabkan banyak anak yang terpaksa harus bekerja untuk membantu mencukupi kebutuhan ekonomi keluarganya. 
Anak-anak yang bekerja umumnya tidak mendapat perlindungan yang seharusnya, mendapat upah yang rendah dan seringkali mengalami eksploitasi. Banyak pengusaha yang mau menerima tenaga pekerja anak karena umumnya mereka dibayar murah dan tidak banyak menuntut. Secara umum pekerja anak dapat digambarkan sebagai berikut: (a)Pekerja anak tersebar di daerah pedesaan dan perkotaan, di pedesaan anak bekerja di bidang pertanian, perkebunan, perikanan, pertambangan, maupun kegiatan ekonomi keluarga, sedangkan di perkotaan anak bekerja di perusahaan, rumah tangga dan jalanan.(b) adanya steriotipe di kalangan masyarakat yaitu dengan masih didominasi struktur sosial dan budaya yang berpandangan bahwa anak ditempatkan dalam wilayah keluarga (domestik) sehingga anak cenderung menjadi korban (obyek dari kekerasan, eksploitasi, diskriminasi dan perlakuan salah.

Di Kabupaten Kapuas Hulu, pekerja anak-anak pada usia 10-14 tahun terindikasi pada bentuk-bentuk pekerjaan membantu orang tua yang sebagian besar, hidup sebagai petani tradisional, sebagai penangkap ikan, dan membantu dalam perkebunan. Pekerja anak membantu orang tua adalah anak yang tinggal di desa dan biasanya dilakukan saat mereka pulang sekolah dan hari libur sekolah.

(2) Pelacuran/ pekerja seks komersial.Perdagangan perempuan kini makin marak. Para perempuan korban perdagangan dipekerjakan sebagai pekerja seks komersial di kota-kota besar di Indonesia dan luar negeri.

\section{Faktor Yang Mempengaruhi Terjadinya Trafficking}

Berbagai macam modus operandi trafficking yang terjadi di Kabupaten Kapuas Hulu banyak dipengaruhi oleh beberapa faktor yang berbeda di masing-masing modus operandi, antara lain: (1) Dibukanya Pos Lintas Batas (PLB) Entikong Kabupaten Sanggau. Kalimantan Barat merupakan salah satu provinsi yang langsung berbatasan dengan negara asing, yaitu Negara Bagian Serawak, Malaysia Timur. Dengan demikian Kalimantan Barat satu-satunya Provinsi di Indonesia yangmempunyai akses jalan darat untuk masuk/ keluar ke negara asing. Tidak kurang terdapat 50 jalur jalan setapak yang menghubungkan 55 desa di Kal-Bar dengan 32 Kampung di Serawak, sementara yang disepakati kedua negara ada 10 desa yang dapat digunakan untuk jalur masuk yang menghubungkan 7 buah kampung di Serawak. Dengan 14 Kecamatan yang berbatas langsung dengan Serawak (Kecamatan Sambas 2, Kec.Sintang 2, Kec. Bengkayang 2 dan Kec. Kapuas Hulu 6). Pos lintas batas di Entikong yang resmi dibuka tahun 1991 oleh Presiden Soeharto dapat ditempuh dari Pontianak dengan perjalanan selama lebih kurang 8 jam atau 10 jam dengan menggunakan bus atau kendaraan roda empat. Selain jalur 
resmi Entikong pada awal Agustus 1999 telah dibuka lagi jalur PLB, yaitu di Kecamatan Badau Kabupaten Kapuas Hulu. Dibukanya Pos Lintas Batas (PLB) Entikong Kabupaten Sanggau, Kalimantan Barat menyebabkan terdapat akses jalan darat untuk mempermudah arus masuk keluar negeri, terutama Malaysia meskipun ada pemeriksaaan di pos tersebut. Upaya pelaku untuk membawa korban ke Malaysia dapat lolos dengan berbagai cara.(2) Adanya jalan setapak di Kecamatan Badau yang menghubungkan beberapa desa di Malaysia. Upaya pelaku tindak perdagangan perempuan dan anak ada yang melewati jalan tikus di Kapuas Hulu (Badau). Berdasarkan data Pemerintah Kalimantan Barat, terdapat sekitar 60 jalan tikus atau jalan setapak yang menghubungkan antara Kalimantan Barat dengan Malaysia Timur (Sarawak) sehingga rawan digunakan untuk kegiatan yang sifatnya tidak resmi. Dengan adanya Pos Lintas Batas (PLB) di Kecamatan Badau ( Kota Nanga Badau ) Kabupaten Kapuas Hulu lintas ke Malaysia lebih mudah dan lebih cepat jarak Nanga Badau-Lubuk Hantu. Perjalanan itu dapat ditempuh dengan kendaraan darat selama 15 menit.(3) Kemiskinan. Faktor penyebab yang erat hubungannya dengan perdagangan perempuan dan anak berdasarkan jenis pekerjaan tersebut adalah faktor kemajuan ekonomi di Malaysia, sedangkan di wilayah Badau saat ini kesempatan kerja berkurang. Pada saat Badau masih ramai dengan maraknya illegal logging, kondisi ekonomi warga setempat cukup baik. Dengan dilarangnya illegal logging, Badau menjadi kota sepi. Di desa Lanjak banyak anak yang pergi ke Serawak untuk mencari nafkah; bahkan mereka pergi dengan mengorbankan kesempatan menempuh pendidikan di sekolah. Mereka berpendapat, lebih baik mendapatkan uang di Serawak daripada memperoleh ilmu di sekolah. Hal itu terus terjadi walaupun sudah banyak pengarahan dari pihak sekolah dan desa. Para guru selalu mengajarkan, bahwa pendidikan merupakan modal masa depan. Para aparat desa melalui berbagai kesempatan juga telah memberikan penjelasan pentingnya pendidikan.

(4) Ketimpangan ekonomi sektoral antar daerah/ negara. Adanya ketimpangan ekonomi antar wilayah perbatasan Indonesia di kalimantan Barat dan kota-kota perbatasan di Serawak. Kebutuhan sehari-hari wilayah perbatasan diperoleh dari kota-kota kecil di perbatasan Serawak dan Kalimantan Barat dan sebaliknya warga perbatasan (Badau) menjual hasil bumi di Kota Malaysia (Serawak). Hal ini disebabkan oleh akses ke Malaysia untuk mendapatkan barang-barang kebutuhan primer lebih murah harganya dan mudah dijangkau oleh masyarakat Badau dari pada ke Kabupaten Puttusibau yang harus menempuh jarak 6 jam dengan angkutan umum (Bus) yang hanya berjumlah 2 armada; bahkan mulai bulan april tahun 2009, listrik di hampir seluruh wilayah perbatasan di supply oleh Pemerintah Malaysia. Sebelumnya masyarakat perbatasan hanya menggunakan diesel untuk menyalakan listrik, dan pada 
pukul 00.00 listrik akan mati.(5) Pekerja migran.Adanya pekerja Indonesia yang sukses bekerja di luar negeri mendorong lainnya ingin bekerja di luar negeri karena iming-iming penghasilan yang lebih besar tanpa mempertimbangkan resiko dan Peraturan Pemerintah yang harus dipatuhi. Di Badau Kapuas Hulu, sebagian warga mengandalkan sistem kekerabatan, karena adanya keluarga mereka yang bekerja di Malaysia (Serawak). Mereka umumnya satu suku yaitu Suku Dayak Iban. Orang-orang suku Dayak Iban menyakini bahwa nenek moyang mereka masih ada tali persaudaraan dengan warga atau orang-orang Malaysia di Sarawak sehingga ketika mereka merantau ke Malaysia, mereka merasa aman karena banyak saudara-saudara mereka yang tinggal di Malaysia.(6) Ketimpangan sektor kesehatan dan pendidikan.Ada ketimpangan di sektor kesehatan dan pendidikan antarwilayah perbatasan Indonesia di kalimantan Barat dan kota-kota perbatasan di Serawak. Fasilitas pendidikan dan kesehatan yang diberikan oleh Pemerintah Malaysia, berupa pelayan kesehatan gratis dan pendidikan gratis bagi masyarakat di Kecamatan Badau yang melahirkan anaknya di Malaysia. Selain itu, mereka juga mendapatkan hak kewarganegaraan Malaysia. Masyarakat di Kecamatan Badau lebih memilih anaknya dilahirkan di Malaysia demi mendapatkan kemudahan fasilitas pendidikan dan kesehatan.

\section{Upaya Pencegahan Trafficking Di Kabupaten Kapuas Hulu}

Beberapa upaya pencegahan trafficking perempuan dan anak yang telah dilakukan oleh Pemerintah Daerah Kapuas Hulu beserta jajarannya serta anggota masyarakat adalah: (1) Sosialisasi kepada masyarakat (penduduk) di tingkat kecamatan atau kawasan tertinggal untuk mencegah keluarga perempuan mereka dibiarkan putus sekolah dan terdorong untuk bekerja di kota besar atau luar negeri.(2) Dengan dibentuknya bagian pemberdayaan perempuan pada pemerintahan Kabupaten Kapuas Hulu dan adanya rencana strategis pemberdayaan perempuan, pengarusutamaan gender dapat berjalan dengan baik.(3) Dengan adanya Pos Lintas Batas Badau pihak imigrasi dapat melaksanakan pengawasan terhadap lalu lintas warga yang akan ke Serawak, demikian pula sebaliknya. Warga yang akan ke wilayah Serawak harus dapat menunjukkan Paspor sesuai ketentuan yang berlaku. Paspor putih untuk perjalanan sehari, sedangkan paspor merah berlaku untuk selama 30 hari. Jumlah personil di Kecamatan Badau masih sangat minim. Pejabat imigrasi dan bea cukai masing-masing 2 orang. Pejabat keamanan terdiri dari 100 orang personil TNI dan 23 personil Polisi. Dengan jumlah seperti itu akan sangat sulit para pejabat pemerintah untuk mengkoordinasikan dalam pengawasan dan pencegahan perdagangan manusia. Dengan adanya kondisi tersebut, pemerintah Kabupaten Kapuas Hulu memperbaiki infrastruktur, sarana dan 
prasarana, SDM di Kecamatan Badau khususnya di Kota Nanga Badau.(4) Dinas tenaga Kerja dan Transmigrasi juga telah melaksanakan sosialisasi masalah ketenagakerjaan, tetapi untuk pengawasan terhadap tindak pidana perdagangan manusia, masih terkendala tenaga pengawas karena untuk melaksanakan tugas ini pegawai harus mengikuti pelatihan selama sembilan bulan untuk mendapatkan sertifikasi. Hal ini sudah dilaporkan ke Pusat, tetapi belum memperoleh perhatian.(5) Untuk mengurangi kemiskinan di wilayah Kabupaten Kapuas Hulu. Pemerintah Kabupaten Kapuas Hulu telah memiliki rencana strategis pengentasan kemiskinan secara terpadu. Wilayah Kabupaten Badau merupakan wilayah utama pengembangan ekonomi di bagian utara Kabupaten Kapuas Hulu.(6) Masalah pendidikan telah menjadi prioritas di wilayah Kabupaten Kapuas Hulu baik pendidikan formal dan informal. (7) Dinas Kesehatan Kabupaten Kapuas Hulu telah melaksanakan upaya peningkatan kualitas pelayanan kesehatan melalui peningkatan sarana dan SDM. Khususnya di wilayah Badau, juga diupayakan pencegahan dan penanggulangan penyakit HIV/ AIDS dengan cara melakukan survei dan penyuluhan setiap tiga bulan sekali bekerja sama dengan mobile VCT dari Pontianak, selain itu juga membentuk komisi Penanggulangan AIDS di tingkat kabupaten.

\section{Upaya Perlindungan Korban Trafficking}

Di Kabupaten Kapuas Hulu juga telah dilakukan upaya perlindungan kepada korban tindak pidana perdagangan perempuan dan anak. Apabila ada kasus akan segera ditangani oleh yang berwajib. Sampai saat ini di Kapuas Hulu belum ada lembaga yang menangani korban tindak perdagangan setelah dikembalikan ke Indonesia. Lembaga yang menangani baru terdapat di tingkat Provinsi, yang berada di Pontianak di antaranya : (1) Pusat Pelayanan Terpadu Pemberdayaan Perempuan dan Anak (P2TP2A) Kalimantan Barat. (2) PWA Aisyiah Kalimantan Barat melalui Majelis Kesejahteraan Sosial (MKS) dan Lembaga Hubungan Organisasi, Hukum dan Advokasi (LHOHA). Aisyiah Kalimantan Barat telah melaksanakan penyebarluasan informasi mengenai advokasi terhadap korban trafficking, yang dilakukan oleh Lembaga kepada instansi luar negeri, khususnya negara-negara tujuan TKW. Aisyiah Kalimantan Barat juga membina korban trafficking yang semula menjadi PRT, PSK, dan buruh di Malaysia serta Arab Saudi untuk dapat hidup mandiri. Pemerintah Daerah bekerja sama dengan lembaga-lembaga tersebut untuk menangani korban trafficking perempuan dan anak.(3) Di Kecamatan Badau telah ada sebuah Paguyuban "Podo Rukun" yaitu Shelter atau tempat penampungan sementara bagi korban trafficking sebelum mendapat tindakan lebih lanjut. Menurut penuturan ketua paguyuban, korban-korban trafficking 
yang melarikan diri dari Malaysia menuju Badau. Mereka di tampung. Korban perempuan, langsung diberi ongkos, kemudian dipulangkan ke daerah asalnya. Korban laki-laki, diberi dua pilihan yaitu tinggal di Badau dan dicarikan pekerjaan atau diberi ongkos untuk pulang ke daerahnya. Dari beberapa korban, ada yang tetap tinggal di Badau; bahkan sampai menikah dengan masyarakat setempat dan ada pula yang memilih untuk pulang ke daerahnya.

Hal-hal yang masih perlu diupayakan oleh Pemerintah Kabupaten Kapuas Hulu dalam upaya pencegahan perdagangan perempuan dan anak adalah: (1) menindaklanjuti Peraturan Daerah Provinsi Kalimantan Barat Nomor 7 Tahun 2007 tentang Pencegahan dan Pemberantasan Perdagangan Manusia dengan menerbitkan Peraturan Bupati tentang Pelaksanaan upaya pencegahan dan perlindungan terhadap perdagangan manusia di Kabupaten Kapuas Hulu. Peraturan ini berisi pedoman pelaksanaan upaya tersebut di atas, yang berlaku di Kabupaten Kapuas Hulu. Dengan adanya Peraturan Bupati landasan hukum yang diperlukan untuk pelaksanaan operasional program atau kegiatan tersebut, dan akan mempermudah untuk mendapatkan anggaran dalam APBD.(2) membentuk Gugus Tugas Daerah Kabupaten Kapuas Hulu, yang disahkan dengan Surat Keputusan Bupati. Anggota Gugus Tugas adalah wakil-wakil dari pemerintah, penegak hukum, organisasi kemasyarakatan, lembaga swadaya masyarakat, organisasi profesi, dan peneliti/akademisi. Kegiatan yang dilakukan adalah: (a) mengkoordinasikan upaya penegahan dan pemberantasan tindak pidana perdagangan orang, terutama perempuan dan anak. (b) melaksanakan advokasi, sosialisasi, pelatihan, dan pemberdayaan ekonomi serta kerja sama.(c) memantau perkembangan penegakan hukum serta melaksanakan pelaporan dan evaluasi.(d) meningkatkan secara optimal kampanye dan sosialisasi kepada masyarakat melalui media massa, kelompok masyarakat, tokoh-tokoh masyarakat, dan sebagainya, stakeholders, aparat desa. Adapum materi sosialisasi terutama Undang-undang Republik Indonesia Nomor 21 tahun 2007 tentang Pemberantasan Tindak Pidana Perdagangan Orang, Peraturan Daerah Provinsi Kalimantan Barat Nomor 7 Tahun 2007 pasal 2 ayat 2 yang berbunyi bahwa"Tidak ada seorang terutama perempuan dan anak dapat diperdagangkan melalui ketenagakerjaan, perkawinan, dengan cara direkrut, dikumpulkan, diangkat dan dipindahkan dengan tujuan eksploitasi untuk suatu pekerjaan tertentu maupun untuk suatu pekerjaan dalam kegiatan pelacuran", 16 serta Peraturan perundang-undangan lainnya yang terk ait. (3) meningkatkan peran serta masyarakat dalam pencegahan tindak pidana perdagangan orang, mulai dari tingkat RT, RW, Dusun, dan Desa hingga Kabupaten. Tokoh-tokoh masyarakat perlu berperan serta dalam tindak pencegahan. Peran yang diharapkan adalah: (a) memberikan penyuluhan kepada warga setempat. (b) ikut mencegah orang-orang yang akan merekrut perempuan dan anak desa 
tersebut untuk dibawa ke luar wilayah. (c) melaporkan kepada yang berwajib apabila menemukan perdagangan orang. (4) Dalam bidang pendidikan, perlu diupayakan berbagai jenis pendidikan luar sekolah untuk kaum perempuan, dengan memanfaatkan modul-modul yang telah dikembangkan oleh Subdit. Pendidikan Perempuan Direktorat Pendidikan Masyarakat, Depdiknas. Modul yang penting untuk diterapkan dalam kaitannya dengan pencegahan perdagangan perempuan adalah: pendidikan tentang pencegahan trafficking dan pembekalan calon tenaga kerja wanita, peningkatan pendidikan luar sekolah bagi perempuan termasuk pendidikan keterampilan dan keaksaraan fungsional, dan sebagainya. (5) Perlu adanya program khusus Pemberdayaan Ekonomi di wilayah Kecamatan Badau, untuk mencegah perempuan dan anak bekerja ke Malaysia. Pemberdayaan Ekonomi disesuaikan dengan potensi yang ada di wilayah Kecamatan Badau, seperti kerajinan tangan, perikanan dan wisata. Pengrajin manik-manik perlu mendapat pembinaan khusus. Di Badau juga dapat dikembangkan obyek wisata baru, misalnya rumah bentang. Pemerintah Kabupaten Kapuas Hulu perlu mendatangkan investor yang bersedia membangun sarana yang bersifat manufaktur sehingga mampu menciptakan lapangan kerja di wilayah tersebut. (6) Di sektor tenaga kerja perlu meningkatkan SDM Pengawas tenaga kerja di lapangan, dan menerbitkan peraturan Bupati tentang pengiriman tenaga kerja wanita ke luar wilayah Kapuas Hulu. (7) meningkatkan kerja sama dengan pemerintah daerah Kabupaten/Kota di Kalimantan Barat, dalam pencegahan trafficking perempuan dan anak.

\section{SIMPULAN}

Berbagai jenis pekerjaan yang dilakukan perempuan dan anak korban trafficking di Kabupaten Kapuas Hulu adalah pekerja di tempat hiburan, buruh perkebunan atau pabrik, pekerja migran, buruh perkebunan kelapa sawit, buruh perkebunan kayu lapis, pekerjaan-pekerjaan yang bersifat eksploitatif, dan pelacuran (pekerja seks komersial) terselubung. Adapun faktor-faktor yang mempengaruhi terjadinya perdagangan perempuan dan anak ialah dibukanya Pos Lintas Batas (PLB) Entikong di Kabupaten Sanggau Kalimantan Barat, adanya jalan setapak ke Malaysia di wilayah perbatasan, kemiskinan di wilayah Kalimantan Barat, ketimpangan ekonomi struktural antar-daerah atau negara, ketimpangan pendidikan dan kesehatan. Adanya pekerja migran Indonesia di Malaysia juga menjadi faktor pemicu terjadinya trafficking.

Di Kabupaten Kapuas Hulu juga telah dilaksanakan upaya pencegahan trafficking perempuan dan anak baik oleh Pemerintah Daerah maupun masyarakat. Upaya yang dilakukan berupa: (a). Sosialisasi kepada masyarakat di tingkat kecamatan atau kawasan tertinggal untuk mencegah keluarga 
perempuan mereka dibiarkan putus sekolah dan terdorong untuk bekerja di kota besar atau luar negeri; (b). dibentuknya bagian pemberdayaan perempuan pada pemerintahan Kabupaten Kapuas Hulu dan adanya rencana strategis pemberdayaan perempuan, sehingga pengarusutamaan gender dapat berjalan dengan baik; (c). pihak imigrasi dapat melaksanakan pengawasan terhadap lalu lintas warga yang akan ke Serawak, demikian pula sebaliknya. (d). Dinas tenaga Kerja dan Transmigrasi melaksanakan sosialisasi masalah ketenagakerjaan, khususnya pengawasan terhadap tindak pidana perdagangan manusia. (e). Usaha pengetasan Kemiskinan secara terpadu serta (f). Memprioritaskan program pendidikan dan kesehatan.

Upaya perlindungan korban tindak pidana perdagangan perempuan dan anak yang dilakukan pihak pemerintah kabupaten adalah penanganan kasus yang ditangani secara cepat oleh yang berwajib. Beberapa lembaga di daerah yang secara khusus menangani korban tindak perdagangan setelah dikembalikan ke Indonesia antara lain adalah Pusat Pelayanan Terpadu Pemberdayaan Perempuan dan Anak (P2TP2A) Kalimantan Barat dan PWA Aisyiah Kalimantan Barat melalui Majelis Kesejahteraan Sosial (MKS) dan Lembaga Hubungan Organisasi, Hukum dan Advokasi (LHOHA) serta paguyuban "Podo Rukun" yang menyediakan shelter atau tempat penampungan sementara bagi korban trafficking sebelum mendapat tindakan lebih lanjut.

\section{Endnotes:}

1 Suyanto.2008. Modul Pendidikan untuk Pencegahan Trafficking, Jakarta. Direktorat Pendidikan Masyarakat, Direktorat Jenderal Pendidikan Luar Biasa Departemen Pendidikan Nasional

2 Suyanto. 2007. Undang-Undang Republik Indonesia. Nomor 21 Tahun

3 Koalisi Perempuan Indonesia, Direktorat Pendidikan Masyarakat, 2008

4 www. rahima.or.id, dimuat tgl 29 Juli 2009). Dalam Perempuan Indonesia 2005/2006

5 www.bkkbn.go.id, dimuat tgl 22 Pebruari 2005

6 Suyanto. 2002. Perdagangan Anak Perempuan "Kekerasan Seksual dan Gagasan Kebijakan". Seri Laporan No.117: Yogyakarta, PSKK UGM dan Ford Foundation.

7 Suyanto

8 Devi Rahayu dalam Women In Public Sector (Perempuan di sektor publik). Yogyakarta, Tiara Wacana. Pusat Studi wanita UGM.

$9 \quad$ Ibid

10 www.detik.com dimuat pada tanggal 18 Januari 2006

11 Kedaulatan Rakyat, 14 Desember 2007 
16 Suyanto. 2007. Op.Cit

\section{DAFTAR PUSTAKA}

http:/ / epaper.republika.co.id diakses pada tanggal 07 Juni 2009

Kedaulatan Rakyat, Selasa Legi, 13 Januari 2009

Kedaulatan Rakyat, Kamis Legi, 2 Juli 2009

Kedaulatan rakyat, Kamis Wage, 5 Februari 2009

Kedaulatan rakyat, Minggu Pon, 23 Agustus 2009

Solidaritas Perempuan. 2000. Dalam Praktik Panduan Melawan Perdagangan Perempuan dan anak. Jakarta.

Suyanto. 2002. Perdagangan Anak Perempuan Kekerasan Seksual dan Gagasan Kebijakan. Seri Laporan No.117: Yogyakarta: PSKK UGM dan Ford Foundation.

2008. Modul Pendidikan untuk Pencegahan Trafficking, Jakarta: Direktorat Pendidikan Masyarakat, Direktorat Jenderal Pendidikan Luar Biasa Departemen Pendidikan Nasional

2004. Jurnal Perempuan 36 Pendampingan korban Trafficking.

Jakarta: Yayasan Jurnal Perempuan

2007. Pedoman Standar Operasional Pemulangan dan Reintegrasi

Korban Perdagangan Orang (PSO PRKPO). Jakarta: Kementrerian Negara Pemberdayaan Perempuan Republik Indonesia.

2007. Statistik Gender dan Analisis di Kabupaten Kapuas Hulu

Tahun 2007. Kalimantan Barat: Kementerian Negara Pemberdayaan Perempuan Republik Indonesia.

2007

2007. Undang-Undang Republik Indonesia. Nomor 21 Tahun

. 1984. Undang-Undang Republik Indonesia. Nomor 7 Tahun

1984

2008. PP. Republik Indonesia. Nomor 9 Tahun 2008

2007. Himpunan undang-Undang yang berkaitan dengan

kebijakan Perlindungan Anak. Jakarta: Kementerian Negara Pemberdayaan

Perempuan Republik Indonesia. 
www.kompas.com dimuat pada tanggal 7 November 2006

www. idlo.int/bandaacehawareness.HTM diakses pada tanggal 5 Juni 2009

www.news.id.inroll.com diakses pada tanggal 25 Februari 2009

www. rahima.or.id, dimuat tgl 29 Juli 2009

www.bkkbn.go.id, dimuat tgl 22 Pebruari 2005 